\title{
Proslave tisućgodišnjice Hrvatskoga Kraljevstva u Bosni i Hercegovini s posebnim osvrtom na Mostar
}

IVICA GLIBUŠIĆ

Sveučilište u Mostaru

Filozofski fakultet

E-pošta: ivica.glibusic@ff.sum.ba
UDK: 061.6:94(497.6)

Prethodno priopćenje

Primljeno: 6. ožujka 2020.

Prihvaćeno: 10. lipnja 2020.

\section{Sažetak}

Autor u ovom članku na temelju arhivske građe, onodobnog tiska i znanstvene literature donosi dio proslava tisućgodišnjice Hrvatskoga Kraljevstva u Bosni i Hercegovini s posebnim osvrtom na proslavu u Mostaru. Cilj je rada prikazati prilike u kojima je proslavljena tisućgodišnjica Hrvatskoga Kraljevstva u Bosni i Hercegovini, odnosno što je dovelo do novih podjela i politizacije oko proslave tako da su u Sarajevu i Mostaru održane dvije proslave, jedna u srpnju a druga u rujnu. Posebno je bila u Mostaru izražena podjela, što je posljedica utjecaja političkih stranaka, napose Hrvatske seljačke stranke koja je imala apsolutnu podršku Hrvata u $\mathrm{BiH}$.

U organiziranju obilježavanja tisućgodišnjice Hrvatskoga Kraljevstva u Bosni i Hercegovini glavnu riječ vodilo je Hrvatsko kulturno društvo Napredak kao nestranačka organizacija iako je $\mathrm{u}$ svojim redovima imalo političare, javne djelatnike i istaknute crkvene osobe. Hrvatska seljačka stranka nastojala je obilježava- 
Ivica Glibušić - Proslave tisućgodišnjice Hrvatskoga Kraljevstva...

nje spomenute obljetnice iskoristiti za svoju promidžbu i jačanje stranačkih redova koji su se poljuljali nakon ulaska u vladu sa srpskim radikalima. Hrvatska pučka stranka u Hercegovini uz pomoć svoga članstva podržala je srpanjsku proslavu koja je održana na poticaj Katoličke Crkve a istovremeno je nastojala prikazati kao štetno za Hrvate približavanje Hrvatske seljačke stranke srpskim radikalima, odnosno formiranje zajedničke vlade. Obilježavanjem ove obljetnice Hrvati u Bosni i Hercegovini dodatno su ojačali nacionalnu svijest i potaknuli izgradnju nacionalnog identiteta, unatoč nepovoljnim prilikama u Kraljevini Srba, Hrvata i Slovenaca, i to kroz niz manifestacija na kojima se isticala važnost obljetnice Hrvatskoga Kraljevstva. Proslave su organizirane po cijeloj Bosni i Hercegovini gdje su Hrvati činili značajan udio u lokalnom stanovništvu. O tim događajima svjedoče nam podignuti spomenici u čast kralju Tomislavu, izgrađene crkve, imenovani trgovi i ulice od Bosanskog Šamca preko Sarajeva, Tomislavgrada, Livna, Mostara, Čapljine i drugih manjih mjesta.

Ključne riječi: tisućgodišnjica Hrvatskoga Kraljevstva; Napredak; Hrvatska seljačka stranka; Katolička Crkva; franjevci; Hrvatska pučka stranka.

\section{Uvod}

Proslave tisućgodišnjice Hrvatskoga Kraljevstva održane su u više gradova na prostoru današnje Hrvatske i Bosne i Hercegovine. Međutim, zasigurno su ostale najpoznatije zagrebačke i sarajevske proslave. Naime, u Zagrebu su održane četiri proslave a u Sarajevu dvije. Proslavama ovoga jubileja u samostalnoj Hrvatskoj posvetilo se mnogo pozornosti, posebno kada je riječ o proslavama u Zagrebu a nešto manje onim na drugim prostorima Hrvatske. Što se tiče Bosne i Hercegovine obrađene su proslave u Tomislavgradu i u Sarajevu. O proslavi u Tomislavgradu objavljen je vrijedan Zbornik radova sa znanstvenog simpozija Fra Mijo Čuić - graditelj i uznik. U prigodi 50 obljetnice smrti (1959.-2009.). ${ }^{1}$ O proslavi u Sarajevu znanstveni članak pod naslovom "Ministar Pavle Radić na 'Napretkovoj' proslavi tisućgodišnjice hrvatskog kraljevstva u Sarajevu 1925. godine" obja-

1 Robert Jolić - Jure Krišto (prir.), Fra Mijo Čuić - graditelj i uznik. U prigodi 50 obljetnice smrti (1959.-2009.), Mostar - Tomislavgrad, 2009. 
vio je Zlatko Matijević. ${ }^{2} \mathrm{U}$ ovom se radu ovim dvjema proslavama ne ćemo opsežnije baviti jer nam je cilj prikazati načine obilježavanja tisućgodišnjice Hrvatskoga Kraljevstva u pojedinim mjestima Bosne i Hercegovine s posebnim osvrtom na Mostar. O mostarskoj proslavi na temelju onodobnoga tiska pisao je Zlatko Matijević u knjizi $U$ sjeni dvaju orlova. ${ }^{3}$ Velik doprinos boljem razumijevanju važnosti obilježavanja ove obljetnice, kako na prostorima Hrvatske, tako i Bosne i Hercegovine, dao je Mario Jareb u svom djelu Kralj Tomislav kroz tisuć godina: Kralj Tomislav između stvarnosti i mita te proslava tisućite obljetnice Hrvatskoga Kraljevstva 1925. godine i njezini odjeci do danas. ${ }^{4}$ Kako bi se dodatno rasvijetlili događaji vezani za proslavu u Mostaru i pojedinim mjestima u Bosni i Hercegovini korištena je arhivska građa Arhiva Bosne i Hercegovine u Sarajevu, Arhiva Hercegovačke franjevačke provincije u Mostaru, Arhiva Franjevačkog samostana na Gorici, tisak i znanstvena literatura koja se bavi ovom problematikom.

\section{Pripreme za proslave tisućite obljetnice}

Iako se u novijoj hrvatskoj historiografiji navodi kako je ideja o proslavi tisućgodišnjice Hrvatskoga Kraljevstva 1925. potaknuta od Družbe "Braća Hrvatskoga Zmaja" (DBHZ), Mario Jareb navodi kako se ta ideja pojavila ranije. Ideja za obilježavanje tisućgodišnjice Hrvatskoga Kraljevstva iz 1900. godine veže se uz fra Ljudevita Radoša i njegove suradnike. ${ }^{5}$ Ideja o obilježavanju ove obljetnice pojavila se i kod drugih bosanskohercegovačkih Hrvata. Posebno treba istaknuti Antu Jukića koji je bio učitelj u gradskoj pučkoj školi u Mostaru i radio na promicanju hrvatskoga pokreta. Već se 1901. zalagao za početak priprema oko proslave obljetnice nadajući se napretku narodne hrvatske misli u Bosni i Hercegovini. ${ }^{6}$ Iza inicijative o potrebi

2 Zlatko Matijević, "Ministar Pavle Radić na 'Napretkovoj' proslavi tisućgodišnjice hrvatskog kraljevstva u Sarajevu 1925. godine", u: Ćasopis za suvremenu povijest, Zagreb, 3/2004., str. 1127-1149.

3 Zlatko Matijević, U sjeni dvaju orlova, Golden marketing - Tehnička knjiga, Zagreb, 2005., str. 212-214.

4 Mario Jareb, Kralj Tomislav kroz tisuć godina: Kralj Tomislav između stvarnosti $i$ mita te proslava tisućite obljetnice Hrvatskoga Kraljevstva 1925. godine i njezini odjeci do danas, Hrvatski institut za povijest - Družba "Braća Hrvatskoga Zmaja", Zagreb, 2017.

5 Isto, str. 77.

6 Isto, str. 80. 
Ivica Glibušić - Proslave tisućgodišnjice Hrvatskoga Kraljevstva...

Nacionalne proslave tisućgodišnjice Hrvatskoga Kraljevstva 1925., stala je DBHZ 1906. godine. Kako se približavala obljetnica, toj se inicijativi 1917. pridružio duvanjski nadžupnik fra Mijo Čuić, koji je predložio izgradnju spomen crkve i spomen doma na Duvanjskom polju. Izgleda kako je u tim razgovorima dogovoreno da se crkva posveti sv. braći Ćirilu i Metodu jer su se tako nastojali pridobiti članovi vladajuće Hrvatsko-srpske koalicije iz Banske Hrvatske. ${ }^{7}$ Proslava spomenute obljetnice trebala je završiti izgradnjom spomen bazilike i doma u Duvnu te podizanjem sokolske mogile ${ }^{8}$ (zemljanog humka) i spomenika kralju Tomislavu u Zagrebu. ${ }^{9}$

Kralj Tomislav prisutan je u svijesti brojnih Hrvata prvenstveno zbog priča i legendi nastalih u 19. i početkom 20. stoljeća. Malobrojni sačuvani izvori pokazuju kako je bio važan i moćan vladar a ne bi trebalo biti sporno da je i prvi hrvatski kralj. No izvori ne govore da je 925. postao kralj i da je krunjen na saboru na Duvanjskom polju. Toma Arhiđakon prenosi podatak o njemu kao knezu 914. a suvremeni ga izvori 925. nazivaju kraljem. Prema tome 925. godina bi se mogla uzeti kao godina kada je on postao kraljem. ${ }^{10} \mathrm{Za}$ povjesničare i širu hrvatsku javnost neupitno je da je Tomislav 925. počeo kraljevati. ${ }^{11}$ Iako godina 925 . nije dokazana kao godina krunidbe a Duvanjsko polje kao mjesto krunidbe, ipak su ušli u svijest hrvatske javnosti, a u prošlih stotinu godina i u svijest mnogih povjesničara kao neupitne činjenice s kojima je započinjana svaka priča o prvom hrvatskom kralju. Odraz te povijesne priče jesu i stotine spomen-obilježja podignutih u slavu kralju Tomislavu diljem Hrvatske i Bosne i Hercegovine na kojima je istaknuta 925. godina kao godina njegove krunidbe. ${ }^{12}$ "U jednom od novinskih članaka objavljenih u Hrvatskom braniku iz Mitrovice, današnje Srijemske (Sremske) Mitrovice prvi puta je iznesena ideja o tome kako proslavu valja prirediti na

7 Isto, str. 84.

Gomila (gromila, mogila, tumul), u arheologiji naziv za prapovijesni humak od zemlje ili kamenja, najčešće podignut iznad groba, ali i kao spomen-obilježje ili pak iz obrednih razloga. https://www.enciklopedija.hr (27. 4. 2020.).

9 Vladimir Huzjan, "Uloga Krešimira Filića u proslavi tisuću godina postojanja Hrvatskog kraljevstva u Varaždinu 1925. godine", u: Radovi Zavoda za znanstveni rad HAZU, 23, Varaždin, 2012., str. 75.

10 M. JAReb, Kralj Tomislav kroz tisuć godina, str. 47.

11 Isto, str. 48.

12 Isto, str. 51. 
Duvanjskom polju, ondje, gdje se okrunio prvi naš kralj, na onom polju, od kuda počinje slavna povijest naša. Proslava ne smije biti tek obična proslava, ona mora biti veličanstvena narodna manifestacija, ona mora biti početak nove ere u našem narodu, ona mora biti prvi korak u našem narodnom oslobođenju. (...) ta proslava mora biti proslava cijelog naroda, a ne tek jedne političke stranke."13 DBHZ je u svojoj okružnici, između ostaloga, pozvao Hrvate da prilikom obilježavanja tisućgodišnjice Hrvatskoga Kraljevstva podižu spomenploče i spomenike koji će spominjati hrvatsko tisućgodišnje kraljevstvo. Također se poziva Hrvate da prilikom obilježavanja ove obljetnice podižu spomenploče i spomenike zaslužnim hrvatskim muževima, koji su kroz vjekove radili za hrvatski narod. Upućen je poziv narodu za paljenje krijesova i zvonjavu svih zvona na katoličkim crkvama, a na sam blagdan sv. Ćirila i Metoda preporučeno je da narod pod barjacima polazi u crkve i da se drže predavanja i propovijedi o važnosti ove obljetnice. Uza zahvalu Bogu, za zaštitu i obranu hrvatskoga naroda poziva se Hrvate da sade lipe u spomen tisućgodišnjice Hrvatskoga Kraljevstva, te da se ova obljetnica proslavi dostojanstvenim svečanostima. ${ }^{14} \mathrm{~S}$ biskupske konferencije održane u Đakovu 1924. poslana je Okružnica u kojoj se, između ostaloga, navodi: "Neka slavlje naše tisućgodišnjice bude slavlje katoličkoga hrvatskoga naroda! Neka godina 1925., spomen-godina tisućgodišnjice kraljevstva hrvatskoga bude sveta godina hrvatskog naroda! Neka Tomislavovo slavlje bude jedan veliki zavjet i vječna posveta čitavoga hrvatskoga roda Bogu svojih otaca!"15 Biskupi su istaknuli kako je na pomolu godina 1925., jedna od najznačajnijih godina u životu hrvatskoga naroda. Kao dan obilježavanja tisućgodišnjice Hrvatskoga Kraljevstva biskupi su odredili blagdan Presvetoga Srca Isusova.

$\mathrm{Na}$ okružnicu je kritički reagirao Stjepan Radić, optuživši biskupe da su napisali čisto političko pismo s političkim povodom. Naime, po njegovu mišljenju ovdje nije riječ o vjerskom pismu, nego o želji biskupa da hrvatskom narodu postanu i političke vođe. ${ }^{16}$ Radić je smatrao da je obilježavanje tisućgodišnjice Hrvatskoga Kraljevstva prvenstveno politički događaj a nikako crkveni. Crkva je bila uključena u proslavu od samoga početka, a osim toga izabran je i poseban

13 Isto, str. 77.

14 Isto, str. 126.

15 Z. Matijević, U sjeni dvaju orlova, str. 190.

16 Isto, str. 190-191. 
Ivica Glibušić - Proslave tisućgodišnjice Hrvatskoga Kraljevstva...

odbor za crkvenu proslavu tisućgodišnjice Hrvatskoga Kraljevstva na čijem je čelu bio pomoćni biskup zagrebački Dominik Premuš. ${ }^{17}$

Političke prilike u zemlji, uoči proslave obljetnice Hrvatskoga Kraljevstva, nisu bile nimalo povoljne za Hrvate zbog srpske dominacije koja se provodila u svim sferama javnoga života. Predsjednik Hrvatske republikanske seljačke stranke (HRSS) Stjepan Radić otputovao je u Moskvu gdje je 1. srpnja 1924. učlanio svoju stranku u Seljačku internacionalu, koja je bila ispostava međunarodnoga komunističkog pokreta, pokušavajući internacionalizirati hrvatsko pitanje, odnosno dobiti podršku u svojim političkim aktivnostima u Kraljevini Srba, Hrvata i Slovenaca (Kraljevina SHS). Vlasti u Beogradu iskoristile su taj Radićev potez kao priliku da se na HRSS primjeni protukomunistički Zakon o zaštiti države "Obznana". Na temelju toga 23. prosinca 1924. taj je zakon primijenjen a HRSS je proglašen boljševičkom strankom. Uslijedila su uhićenja vodstva stranke na čelu sa Stjepanom Radićem. ${ }^{18}$ Dok je vodstvo HRSS-a bilo u zatvoru, započeli su i kontakti između kralja s jedne i Nikole Pašića s druge strane te Stjepana Radića s ciljem postizanja dogovora oko normalizacije stanja u zemlji. Unatoč tim pregovorima progon HRSS-ovih dužnosnika i pristaša nastavljao se. Radićevci na terenu nisu bili upoznati s detaljima tih pregovora te je većina članova HRSS-a vijest o zaokretu stranačke politike dočekala s nevjericom. Pavle Radić, kao predsjednik Hrvatskoga seljačkoga kluba, a u ime vođe HRSS-a Stjepana Radića, 27. ožujka 1925. u Narodnoj skupštini pročitao je izjavu u kojoj se priznaje sveukupno stanje definirano "Vidovdanskim ustavom", s dinastijom Karađorđevića na čelu. ${ }^{19}$ Radićeva je izjava bila posve jasna i značila je velik zaokret u politici HRSS-a, priznaje se jedinstvo države, dinastiju Karađorđevića i Ustav na temelju kojega postoji jedan jedinstveni parlament za cijelu državu, a stranka mijenja ime i postaje Hrvatska seljačka stranka (HSS). Time je završeno jedno poglavlje hrvatske politike. Naglim zaokretom HSS-a počinje novo poglavlje u političkom životu cijele državne zajednice. ${ }^{20} \mathrm{U}$ tom vremenu Hrvati su bili izvrgnuti beogradskoj politici centralizma i srbijanskoj dominaciji u političkom, vojnom i gospodarskom životu u Kraljevini SHS.

17 M. Jareb, Kralj Tomislav kroz tisuć godina, str. 116.

18 Z. Matijević, "Ministar Pavle Radić...", str. 1131.

19 Hrvoje Matković, Povijest Hrvatske seljačke stranke, Naklada P.I.P. Pavičić, Zagreb, 1999., str. 191.

20 Isto, str. 192. 
M. Jareb navodi, unatoč takvu stanju, "hrvatske političke snage, hrvatska kulturna i gospodarska elita te brojni predstavnici Katoličke Crkve u Hrvata nastojali su očuvati i promicati hrvatske nacionalne interese, što nije nužno značilo borbu za uspostavu potpuno samostalne hrvatske države". ${ }^{21}$ HSS na čelu sa Stjepanom Radićem bila je vodeća hrvatska politička stranka koja tada nije odbacila opstanak jugoslavenske države uz uvjet da se ona temelji na ravnopravnom položaju Hrvata. ${ }^{22}$ Iako je Radićevo napuštanje republikanizma i pristajanje na centralistički Vidovdanski ustav bilo iznuđeno silom zbog uhićenja njega i drugih istaknutih članova stranke te zabranom rada stranke, Hrvatska pučka stranka (HPS) ocijenila je to Radićevom kapitulacijom i očekivala kako će na idućim izborima ostvariti bolje rezultate nego na prethodnim. Međutim, do velike promjene nije došlo unatoč slabljenju podrške HSS-u. ${ }^{23} \mathrm{~S}$ obzirom da je Radić u Vladu ušao sa srpskim radikalima trebao je Hrvatima a posebno svojim glasačima pokazati kako on i njegova stranka nisu odstupili od nacionalnoga programa i ideje za hrvatsku samobitnost u Kraljevini SHS. Na proslavi tisućgodišnjice Hrvatskoga Kraljevstva u srpnju 1925. u Zagrebu nitko iz HSS-a nije sudjelovao, što se može smatrati politizacijom proslave ove obljetnice s ciljem dobivanja političke koristi. Nakon sporazuma s Narodnom radikalnom strankom, Radić je iskoristio novonastalu situaciju i u kolovozu odlučio sudjelovati u proslavi. ${ }^{24}$ Radićevo približavanje radikalima HSS-ove pristaše u Hercegovini dočekale su s nevjericom. Postavljalo se pitanje o opravdanosti žrtava zbog potpore Radiću. Svojim aktivnim radom HSS-ovo hercegovačko vodstvo za kratko je vrijeme uspjelo spriječiti potpuno rasulo unutar stranke. Unatoč takvim događanjima, HPS nije iskoristio trenutak HSS-ove slabosti da bi sebi privukao sve razočarane u Radićevu politiku što će se pokazati i na sljedećim izborima. ${ }^{25}$ Pavle Radić je također prilikom proslave tisućgodišnjice Hrvatskoga Kraljevstva u Sarajevu opravdavao proces udruživanja $s$ radikalima i isticao kako je to opravdan i mudar čin koji je dobar

21 M. Jareb, Kralj Tomislav kroz tisuć godina, str. 87.

22 Isto.

23 Ivica Glibušić, "Utjecaj koaliranja Hrvatske seljačke stranke sa srpskim radikalima na izborne rezultate 1927. u Bosni i Hercegovini", u: Hercegovina, 5, Mostar - Zagreb, 2019., str. 223.

24 Jure Krišto, Riječ je o Bosni, Golden marketing - Tehnička knjiga, Zagreb, 2008., str. 201-203.

25 I. GLıBušić, "Utjecaj koaliranja Hrvatske seljačke stranke...", str. 217. 
Ivica Glibušić - Proslave tisućgodišnjice Hrvatskoga Kraljevstva...

za budućnost zemlje i za bolji položaj Hrvata i drugih naroda u njoj. Pavle Radić u Hrvatskoj seljačkoj čitaonici na Alipašinu mostu održao je govor u kojemu je istaknuo: "Mi imamo svoju državu svojega kralja svoje zakone. Među nama Hrvatima i Srbima neprijatelji su sagradili veliki zid mržnje. Mi smo za sporazum da se taj zid sruši da se izgrade bolji odnosi među narodima." ${ }^{26}$ Kako bi se suprotstavili Radićevoj politici sporazuma sa srpskim radikalima, glasilo Hrvatske pučke stranke Narodna sloboda $a^{27}$ objavilo je više članaka s ciljem upoznavanja svoga čitateljstva o pogubnoj Radićevoj politici prema Hrvatima a posebno onima u Hercegovini. Također u više članaka problematizira se bojkotiranje Radića i njegovih simpatizera crkvene proslave tisućgodišnjice Hrvatskoga Kraljevstva. U Narodnoj slobodi 3. travnja 1925. objavljen je tekst pod naslovom "Srbi i Hrvati danas i pred tisuću godina" u kojem se naglašava kako je Hrvatska u vrijeme Tomislava bila velika i moćna. Njezine granice sezale su od Albanije do rijeka Drave i Raše u Istri. A jačina vojske od "100 tisuća pješaka 60 tisuća konjanika i na moru što manjih što većih lađa 120". Govori se da je na istoku bila mala i slaba Srbija koju su napali Bugari, a srpski narod s knezom Zaharijom pobjegao je u hrvatske zemlje pod zaštitu kralja Tomislava. Zahvaljujući gostoprimstvu Hrvata, Srbi se naseliše u pojedinim hrvatskim krajevima uključujući i Crnu Goru. Kada su Turci pritiskali Srbiju, Srbi bježe u hrvatske zemlje u 14. i 15. stoljeću. Međutim Srbi, kada su bili u povoljnijim prilikama od Hrvata, stajali su na stranu hrvatskih neprijatelja Mađara, Austrijanaca i Talijana. Posebno se ističe negativno stajalište Svetozara Pribićevića i Nikole Pašića prema Hrvatima nakon stvaranja Kraljevine SHS. ${ }^{28}$ Narodna sloboda svojim člancima potiče neraspoloženje prema Stjepanu Radiću i njegovoj stranci, posebno nakon približavanja srpskim radikalima, kako bi umanjila njegov utjecaj na Hrvate u Hercegovini unatoč tomu što je HSS na izborima 1925. u Hercegovini dobio apsolutnu podršku Hrvata. Također, kada je riječ o hrvatskom biračkom tijelu, na području Bosne HSS je uvjerljivo pobijedio na izborima.

26 "Proslava tisućgodišnjice - slavlje narodnog sporazuma i seljačke politike", u: Dom, 20, Zagreb, 16. rujna 1925., str. 1.

27 List Narodna sloboda je glasilo Hrvatske pučke stranke za Hercegovinu, tiskan je u Mostaru i izlazio je jednom tjedno. List se bavio politikom, prosvjetom i gospodarstvom.

28 "Srbi i Hrvati danas i pred tisuću godina", u: Narodna sloboda, Mostar, 3. travnja 1925., str. 1. 
Kod Hrvata se razvijala misao da povijesne činjenice vezane za kralja Tomislava mogu iskoristiti kao dokaz da su Hrvati imali jaku državu koja se zaštitnički postavila prema Srbima u vrijeme bugarske ekspanzije, te da su Hrvati odigrali ulogu u mirenju južnih Slavena. ${ }^{29}$ Proslavama, posebice onima priređenim prije sklapanja sporazuma između HSS-a i srpskih radikala te izlaska Stjepana Radića iz zatvora, snažno je promican hrvatski nacionalni identitet i narodna posebnost. Proslave 1925. imale su prvenstveno hrvatski plemenski predznak, unatoč tomu što su nakon sporazuma i ulaska HSS-a u vladu isticani i narodno jedinstvo Srba, Hrvata i Slovenaca te veličani kralj Aleksandar i jugoslavenska država. Na svim proslavama isticano je postojanje nekada slobodnoga i samostalnoga Hrvatskoga Kraljevstva dokazujući kako je hrvatski narod sposoban stvoriti vlastitu nacionalnu državu. ${ }^{30}$

U Hrvatskoj nije bilo jedinstvenoga dogovora oko obilježavanja obljetnice Hrvatskoga Kraljevstva pa se u pojedinim gradovima održavalo više proslava ovisno o političkim interesima pojedinih političkih stranaka, udruženja i Katoličke Crkve. "U Zagrebu je 21. lipnja 1925. na blagdan Presvetoga Srca Isusova održana crkvena proslava, zatim je od 4. do 6. srpnja uslijedila prva svjetovna proslava, a druga od 15. do 16. kolovoza vezana uz III. Hrvatski svesokolski slet kojem je prisustvovao i kralj Aleksandar (1888.-1934.). Nakon ove tri proslave, uslijedila je i četvrta koju je 7. i 8. rujna organizirao Jugoslavenski sokolski savez." ${ }^{31}$ Narodna sloboda, glasilo Hrvatske pučke stranke za Hercegovinu, donosi vijest o drugoj (svjetovnoj, od 4.-6. srpnja) veličanstvenoj proslavi u Zagrebu pred 70.000 ljudi na Jelačićevu trgu. Drugi dan te proslave služena je misa zahvalnica u zagrebačkoj katedrali, a nakon toga održana je pučka svečanost u Maksimiru. ${ }^{32}$ Proslava u Zagrebu 15. i 16. kolovoza 1925. bila je u organizaciji Stjepana Radića i njegove stranke (HSS-a). U proslavi i organizaciji ovoga slavlja sudjelovale su i državne vlasti. Beogradska vlada odredila je iznos od 500.000 dinara za potrebe proslave. To se vidjelo i po izaslanstvu koje je stiglo u Zagreb iz Beograda a u kojemu su bili ministri HSS-a i radikalski ministri. ${ }^{33}$ Proslava zakazana 15. i 16. kolovoza 1925. u Zagrebu povezana je s III. Hrvatskim svesokolskim sletom. Nakon

29 M. Jareb, Kralj Tomislav kroz tisuć godina, str. 88.

30 Isto, str. 125.

31 V. Huzjan, "Uloga Krešimira Filića...", str. 76.

32 "Iz Jugoslavije", u: Narodna sloboda, 27, Mostar, 10. srpnja 1925., str. 2.

33 Z. Matijević, "Ministar Pavle Radić...", str. 1133. 
Ivica Glibušić - Proslave tisućgodišnjice Hrvatskoga Kraljevstva...

ove uslijedila je i četvrta proslava tisućgodišnjice Hrvatskoga Kraljevstva 7. i 8. rujna 1925., a organizirao ju je Jugoslavenski sokolski savez. Znakovito je da se Radićevci nisu pridružili toj proslavi. ${ }^{34}$

Po uzoru na Hrvatsku, a slijedom naputka biskupske konferencije, u Bosni i Hercegovini se također pripremalo obilježavanje tisućgodišnjice Hrvatskoga Kraljevstva. Duvanjski nadžupnik fra Mijo Čuić predložio je početkom 1917. da se u svrhu obilježavanja tisućgodišnjice Hrvatskoga Kraljevstva u Duvnu podigne spomen-crkva (bazilika) i Tomislavov dom. Na čelo Društva koje se brinulo o izgradnji spomen-crkve i Tomislavova doma postavljen je fra Mijo Čuić, koji je zamolio zagrebačkoga nadbiskupa dr. Antuna Bauera za pokroviteljstvo toga velikog pothvata, što je on i prihvatio. Kako se radilo o velikom novčanom iznosu potrebnom za izgradnju, Čuić je skupljao novac u domovini i među hrvatskim iseljenicima u Sjedinjenim Američkim Državama. Također, kako bi se što prije realizirao planirani projekt, tražio je i pomoć od kralja Aleksandra. Pred zagrebačkom prvostolnicom 15. lipnja 1924. nadbiskup Bauer blagoslovio je tri temeljna kamena: DBHZ-a, grada Zagreba i plemenite općine Turopolje - za crkvu u Duvnu. Tim je činom u Zagrebu počelo obilježavanje velike obljetnice Hrvatskoga Kraljevstva. Kamen temeljac za spomen-crkvu u Duvnu položen je 8. srpnja 1924. a blagoslovio ga je mostarski biskup Alojzije Mišić. Na toj velikoj svečanosti, osim domaćina fra Mije Čuića i mostarskoga biskupa Mišića, nazočili su: banjolučki biskup Jozo Garić, izaslanstvo DBHZ-a i kraljev osobni izaslanik general Jovanović, koji je odboru za izgradnju spomencrkve uručio vladarov novčani poklon u iznosu od 60.000 dinara. $^{35}$ Zbog nedostatka sredstava crkva je sporo građena tako da je posvećena tek 29. rujna 1940. Tomislavov dom nije nikada izgrađen nego je uza samu crkvu sagrađen franjevački samostan. ${ }^{36}$

Središnja uprava Napretka u Sarajevu izabrala je Odbor za proslavu tisućgodišnjice Hrvatskoga Kraljevstva. Odbor je u razgovorima s vjerskim, civilnim i vojnim vlastima dogovorio da se u Sarajevu 5., 6. i 7. rujna 1925. održi središnja proslava tisućgodišnjice Hrvatskoga Kraljevstva za Bosnu. ${ }^{37}$ Budući da Napredak nije nikakvo političko

34 Isto.

35 http://www.matica.hr - Zlatko Matijević, Kralj Tomislav - prvoborac jugoslavenstva (1. 5. 2020.).

36 M. Jareb, Kralj Tomislav kroz tisuć godina, str. 107.

37 Z. Matijević, "Ministar Pavle Radić...", str. 1135. 
društvo, njegovo je vodstvo inzistiralo na nepolitičkoj dimenziji obilježavanja tisućgodišnjice Hrvatskoga Kraljevstva. Sudjelovanjem u obilježavanju u Sarajevu, HSS je nastojao iskoristiti ovaj događaj u svoju političku korist. Sarajevska proslava, zahvaljujući priređivačkom odboru, imala je u svom programu misu zahvalnicu u sarajevskoj katedrali. Misi je nazočio i Pavle Radić, ministar HSS-a u Vladi Kraljevine SHS. ${ }^{38}$ Glasilo hrvatske seljačke stranke Dom objavilo je na naslovnici članak s naslovom "Proslava tisućgodišnjice - slavlje narodnog sporazuma i seljačke politike" u kojemu se ističe kako je na najvećoj proslavi u Zagrebu bio Stjepan Radić a druga po važnosti je ona u Sarajevu gdje je nazočio Pavle Radić. ${ }^{39}$ Vodstvo HSS-a sa svojim najistaknutijim članovima opravdavalo je pred narodom svoj ulazak u Vladu i suradnju sa srpskim radikalima. Cilj je bio jasan umanjiti štetu koju im je nanio spomenuti sporazum s radikalima.

Međutim, u Sarajevu je 5. srpnja 1925. održana i prva manje poznata Napretkova Ćirilo-Metodska proslava. Podružnica Hrvatskoga kulturnog društva Napredak priredila je 5. srpnja 1925. Ćirilo-Metodsku proslavu na blagdan slavenskih apostola. Prema najavi u svečanoj povorci bila su sva hrvatska društva iz Sarajeva i okolice. Planirano je da društva iz Novoga Sarajeva i okolice polaze u devet sati od Hrvatske čitaonice u Novom Sarajevu ulicom Vojvode Putnika do Marijina dvora, gdje im se priključuju sva ostala društva i građanstvo. Odatle je povorka ulicama (Aleksandrovom i Prestolonasljednika Petra), stigla na svečanu službu Božju u sarajevsku katedralu za vrijeme koje je pjevao, uz pratnju orkestra, veliki zbor "Cecilijina društva". Iz crkve se povorka vratila do Napretkove palače gdje je održan zbor. Poslijepodne je održana velika zabava na igralištu "Saška" (naselje Kovačići) uza sudjelovanje hrvatskoga pjevačkog društva Trebević, Hrvatskoga Katoličkog Ženskog Udruženja, Hrvatska Žena i Hrvatski sokol iz Novog Sarajeva. ${ }^{40}$

38 Isto, str. 1134.

39 "Proslava tisućgodišnjice-slavlje narodnog sporazuma i seljačke politike", u: Dom, 20, Zagreb, 16. rujna 1925., str. 1.

40 Arhiv Bosne i Hercegovine (dalje: ABiH), Napretkova - kulturno historijska zbirka (NKHZ), Plakat "Napretkove" Ćirilo-Metodske proslave 5. srpnja 1925., inventarski broj 912, odsjek I-37/6. 
Ivica Glibušić - Proslave tisućgodišnjice Hrvatskoga Kraljevstva...

\section{Proslave obljetnice}

Po primjeru grada Zagreba i ostalih hrvatskih krajeva i u Hercegovini je 5. srpnja 1925., na poticaj crkvenih vlasti, održana proslava tisućgodišnjice Hrvatskoga Kraljevstva. Već 4. srpnja bila su sva sela hercegovačkih župa u "plamenu" (paljenje krijesova u večernjim satima). Glavna središta u Hercegovini, gdje su se održale proslave, jesu Široki Brijeg, Posušje, Drinovci, Humac, Čitluk i Čapljina. Uz pjesmu i narodnu nošnju, zvonjavu zvona i pucanje iz mačkula, obilježena je ova obljetnica. Jedinu iznimku činio je glavni grad u Hercegovini, Mostar. Narodna sloboda 3. srpnja 1925. najavljuje kako će i u Hercegovini 4. srpnja početi velika proslava tisućgodišnjice Hrvatskoga Kraljevstva uza zvonjavu zvona, paljenjem krijesova te drugim manifestacijama. Međutim, naglašava se kako Hrvati ipak ne će proslaviti taj važan jubilej kako bi ga trebali slaviti, jer ne uživaju pune slobode u novoj državi. Ističe se kako su Hrvati u doba kralja Tomislava imali uređenu državu za razliku od okolnih država a da su imali svoga kralja prije nego Mađarska, Češka ili Poljska ${ }^{41}$ U Posušju je 5. srpnja 1925. održana proslava tisućgodišnjice Hrvatskoga Kraljevstva. Slavlje je započelo okupljanjem stanovništva pred mjesnom crkvom. Povorka se kretala do pučke škole pod hrvatskim zastavama a svečanost je uzveličala Orlovska glazba iz Imotskog. Također, narod predvođen župnikom iz Posuškog Gradca stigao je na proslavu. Glazba je odsvirala Lijepu našu, a nakon toga svečanost se nastavila na Martića križu gdje je održana i svečana misa koju je predvodio fra Tade Beljan. Prema pisanju tadašnjega tiska okupilo se pet do šest tisuća ljudi. ${ }^{42}$ Proslave po Hercegovini nastavile su se u organizaciji svećenstva bez podrške političkih struktura, odnosno HSS-a koji je tada bio na vlasti. U Drinovcima je proslavljena tisućgodišnjica Hrvatskoga Kraljevstva. $\mathrm{Na}$ isti dan bila je i mlada misa koju je slavio don Ilija Tomas. Cijela se Bekija ${ }^{43}$ toga dana pridružila velikoj prosla-

41 "Slava prvom hrvatskom kralju Tomislavu!", u: Narodna sloboda, 26, Mostar, 3. srpnja 1925., str. 1.

42 "Naši dopisi", u: Narodna sloboda, 28, Mostar, 17. srpnja 1925., str. 3.

43 "U ratu g. 1716 do 1718, koji svršio Požarevačkim mirom, Mlečani su dobili nove krajeve na račun kliškoga i hercegovačkoga sandžakata tako, da je tada granica udarena razvodnim planinama Velebitom, Dinarom, Kamešnicom te preko Imotskoga polja i Rastočko-ljubuškoga. Tim mirom Mletačkoj je dodijeljen veći dio imotskog kadiluka, jedan dio Rastočko-ljubuškoga polja i neka mjesta u donjoj Neretvi. Onaj dio imotskog kadiluka, koji je ostao u turskim rukama, nazvao se poslije toga Bekija=ostatak". Dominık Mandić, Bosna $i$ 
vi tisućgodišnjice Hrvatskoga Kraljevstva. ${ }^{44} \mathrm{Na}$ Širokom Brijegu 4. i 5. srpnja 1925. održana je proslava tisućgodišnjice Hrvatskoga Kraljevstva. Obilježavanje obljetnice počelo je pucnjavom iz mačkula. U večernjim satima 4. srpnja po okolnim brdima upaljeni su krijesovi a grad i crkva bili su osvijetljeni i okićeni hrvatskim zastavama. U nedjelju, 5. srpnja, iz okolnih župa došao je narod u pratnji svojih župnika na Široki Brijeg na zajedničku proslavu. Svečanu svetu misu slavio je fra Pavao Dragičević. ${ }^{45}$

$\mathrm{Na}$ Humcu pokraj Ljubuškog 4. srpnja 1925. počelo je obilježavanje tisućgodišnjice Hrvatskoga Kraljevstva pucnjavom iz mačkula, zvonjavom zvona i paljenjem krijesova. Posebno je bilo svečano u večernjim satima toga dana kada su se iznad Ljubuškog na brdima Butorovica i Jurjevica redala svjetla jedno do drugoga u dužini do pet kilometara. Krunu čitave te rasvjete činila je tvrđava hercega Stjepana koja dominira cijelim prostorom. Međutim, prema novinskom tekstu jasno je da je veći dio Ljubušaka bojkotirao tu proslavu. Jedino se pohvaljuje stanovništvo iz sela Radišići zbog svoga dolska na proslavu obljetnice. Također drugi dan na svetu misu na Humcu iz Radišića je u koloni došlo 250-300 osoba noseći hrvatske zastave te su na taj način uzveličali proslavu obljetnice. Misno slavlje predvodio je fra Slavko Luburić. ${ }^{46}$ U općini Konjic, župa Solakova Kula, u čast proslave tisućgodišnjice Hrvatskoga Kraljevstva uz crkvu sv. Ilije Proroka sagrađen je zvonik. Između otvora druge i treće razine, a u njihovoj osovini, postavljena je pravokutna ploča naglašena izvlačenjem iz ravni zida. Na ploči je uklesan sljedeći natpis: "Ovaj zvonik sagradi župa Solakova Kula za župnikovanja V.G. Don Ive Subašića prigodom svete crkvene godine 1925. i hiljadu godišnjice krunisanja prvoga hrvatskoga kralja Tomislava 925-1925".47 Autor projekta katoličke crkve sv. Ilije Proroka iz $1883 .{ }^{48}$ nije poznat, dok je zvonik,

Hercegovina. Državna i vjerska pripadnost sredovječne Bosne i Hercegovine, Ziral, Chicago - Rim, 1978., str. 146.

44 "Naši dopisi", u: Narodna sloboda, 28, Mostar, 17. srpnja 1925., str. 3.

45 "Naši dopisi", u: Narodna sloboda, 27, Mostar, 10. srpnja 1925., str. 3.

46 "Naši dopisi", u: Narodna sloboda, 29, Mostar, 24. srpnja 1925., str. 2.

47 Vidi obrazloženje Odluke Povjerenstva za očuvanje nacionalnih spomenika od 11. listopada 2017., str. 9. Usp. Jusuf Mulić i dr., Konjic i njegova okolina u vrijeme austrougarske vladavine, Sarajevo, ${ }^{2} 2007 .$, str. 38-41.

48 Isto, str. 38-41. 
Ivica Glibušić - Proslave tisućgodišnjice Hrvatskoga Kraljevstva...

prema natpisu na njemu, sagrađen $1925 .{ }^{49}$ prema projektu arhitekta Karla Paržika. ${ }^{50}$

U više mjesta u Bosni i Hercegovini održana je proslava tisućgodišnjice Hrvatskoga Kraljevstva u organizaciji Središnje uprave Napretka te njegovih podružnica uz pripomoć mjesnih hrvatskih i ostalih društava te crkvene i civilne vlasti. ${ }^{51}$ Iz Gradačca je upućen dopis Središnjem odboru Napretka u Sarajevu, da je podružnica Napretka u Gradačcu i Bosanskom Šamcu u zajednici s odborom za gradnju katoličke crkve u Bosanskom Šamcu, odlučila proslaviti tisućgodišnjicu Hrvatskoga Kraljevstva 25. listopada 1925. Tom prilikom posvećena je župna crkva s tornjem visokim 30 metra u kojemu su bila tri zvona. ${ }^{52}$ Programom za obilježavanje obljetnice predviđena je svečana sveta misa uz posvetu katoličke crkve, a nakon mise, svečana povorka krenula bi na gradski trg gdje se tom prigodom treba istaknuti važnost ove proslave. Nakon toga slijedio bi povratak ulicama grada do crkve gdje je predviđen zajednički ručak a tom prigodom prikupljana su sredstva za završetak crkve i za društvo Napredak. ${ }^{53}$ Od središnje uprave Napretka tražili su da pošalju preostale plakate s njihove proslave u Sarajevu "makar im morali nešto i platiti". Osim toga, zatražili su da im se pošalje 1000 komada znački po pet dinara koje su se prodavale prilikom proslave u Sarajevu i 1000 komada znački po deset dinara. Podružnica je predložila da se dio promidžbenoga materijala, ukoliko se ne proda, može vratiti u središnjicu

49 Vidi obrazloženje Odluke Povjerenstva za očuvanje nacionalnih spomenika od 11. listopada 2017., str. 9.

50 Karlo Paržik, (Karel Pařík), bosanskohercegovački arhitekt češkoga podrijetla (Jičín, Češka, 4. VII. 1857. - Sarajevo, 16. VI. 1942.). Nakon rada u Beču došao na preporuku Josipa Vancaša u Bosnu i Hercegovinu, gdje je tijekom gotovo 60 godina djelovanja projektirao u historicističkom stilu javne, stambene i crkvene građevine. Značajnija djela u Sarajevu: hotel Evropa (1882.), Muzej grada Sarajeva (1887.), evangelička crkva (danas Akademija likovnih umjetnosti, 1889.), Narodno kazalište (1897.), Zemaljska štamparija (1908.), Zemaljski muzej (1909.), crkva sv. Josipa (1940.). https://www.enciklopedija. hr (24. 4. 2020.).

51 "Napredak" hrvatski narodni kalendar za prostu godinu 1927., izdao "Napredak" hrvatsko kulturno društvo u Sarajevu 1926., Zapisnik XXII. redovite glavne godišnje skupštine "Napretka" održane od 4. do uključivo 7. srpnja 1926., str. 34.

52 http://garevac.net - Župa Bosanski Šamac (27. 4. 2020.).

$53 \mathrm{ABiH}, \mathrm{HKDN}, 1925$., kutija 33, Arhivski broj (dalje: Arhiv. broj) 848-1186, broj spisa 904/2. 
Napretka u Sarajevo. Upućen je i poziv središnjici Napretka da se pridruži proslavi u Bosanskom Šamcu. ${ }^{54}$

Hrvatska čitaonica i podružnica Napretka u Vitezu uputila je dopis središnjici Hrvatskoga kulturnog društva Napredak u Sarajevu u kojemu ih obavještava kako će se povodom blagdana Male Gospe 8. rujna održati proslava tisućgodišnjice Hrvatskoga Kraljevstva u zajednici s Hrvatskim Sokolom iz Travnika. Za uspomenu toga svečanog dana posadit će se dvije lipe pred Hrvatskim Domom u Vitezu. ${ }^{55}$

Odbor za proslavu tisućgodišnjice Hrvatskoga Kraljevstva u Livnu odlučio je da se slavlje održi 5. rujna 1926. i to podizanjem obeliska prvom hrvatskom kralju Tomislavu na trgu Zrinskoga u Livnu. ${ }^{56}$ Fra Jako Pašalić uputio je 24. kolovoza 1926. poziv Stjepanu Radiću da nazoči proslavi tisućgodišnjice Hrvatskoga Kraljevstva u Livnu. ${ }^{57}$ Radić nije mogao doći u vrijeme proslave ali je ipak 1. studenoga 1926. boravio u Livnu gdje je održao narodni zbor na kojemu se, prema zapisima u Kronici Franjevačkoga samostana Gorica, okupilo malo ljudi (oko 3000), a samo 30 konjanika bilo je na ovome dočeku. ${ }^{58}$ U Kronici se nastoji umanjiti važnost Radićeva dolaska kao i samoga broja sudionika zbog nesklonosti lokalnih franjevaca politici HSS-a. Odbor za proslavu tisućgodišnjice Hrvatskoga Kraljevstva u Livnu tom prigodom tiskao je svečanu pozivnicu u kojoj je naglašena važnost obilježavanja obljetnice. "Prije 1000 godina naši pradjedovi koji su nastanjivali Završje ili Zapadne strane kako se tada zvaše Livno i Duvno s ponosom su gledali krunidbu kralja Tomislava na našem polju. Današnje Livno kao centar Zapadnih strana uzbuđivalo je naš ponos i našu svijest, jačalo rodoljublje kroz tisuću godina u najtmurnijim danima od progona naših dušmana raspirivalo je plamen prema našoj domovini i braći Slavenima i podupiralo oduševljenje te i nakon tisuću godina našega državnog života ojačano je ovim slavljem da se, da novom snagom i s ponosom može uskliknuti - Još nas ima još Hrvata." ${ }^{59}$ Poziv je upu-

54 ABiH, HKDN, 1925., kutija 33, Arhiv. broj 848-1186, broj spisa 904/2.

55 ABiH, HKDN, 1925., kutija 32, Arhiv. broj 461-847, broj spisa 743/1.

56 ABiH, Središnja uprava HKD Napredak 1926., kutija 36, Arhiv. broj 401-1007, Plakat i program proslave u Livnu, broj spisa 854.

57 Arhiv Franjevačkoga samostana Gorica (dalje: AFSG), Fond Jako Pašalić (dalje: Ja. Paš), 7, 1926.

58 AFSG, Kronika FRANJEVaČKoga Samostana na Gorici, Ljet. 1 (kut. 7), str. 269.

59 ABiH, Središnja uprava HKD Napredak 1926., kutija 36, Arhiv. broj 401-1007, Plakat i program proslave u Livnu, broj spisa 854. 
Ivica Glibušić - Proslave tisućgodišnjice Hrvatskoga Kraljevstva...

ćen 8. kolovoza 1926., a prema programu koji je dostavljen uz pozivni plakat okupljanje gostiju planirano je 4. rujna kod slavoluka radi rasporeda konačišta. U večernjim satima održan je sastanak s pristiglim gostima pred zgradom Hrvatskoga glazbeno-pjevačkog društva Dinara odakle je krenula bakljada po gradu s povratkom na isto mjesto gdje se nastavilo druženje uz glazbeni program pjevačkih društava. Drugi dan, 5. rujna 1926., oko šest sati kroz grad je prošla skupina glazbenika svirajući budnicu, a nakon toga održan je sastanak svih društava pred zgradom Hrvatskoga glazbeno-pjevačkog društva Dinara, zatim doček seljaštva i konjaništva te polazak u povorci na misu u samostanskoj crkvi na Gorici. ${ }^{60} \mathrm{Na}$ toj svečanoj svetoj misi pjevao je zbor Dinara. U Kronici franjevačkoga samostana na Gorici zabilježeno je kako je na misnom slavlju sudjelovao biskup Jozo Garić uz mnoštvo naroda ${ }^{61}$ Po završetku istim redom povorka se vratila pred spomenik na Zrinski trg. Prema zapisima u Kronici franjevačkoga samostana spomenik je podignut $\mathrm{u}$ formi obeliska s reljefom kralja Tomislava. $\mathrm{U}$ 12 sati održani su prigodni govori i svečano je otkriven spomenik kralju Tomislavu, visok 9,25 metara, izrađen od bijeloga bračkog kamena. Sprijeda se nalazi reljef kralja Tomislava na konju u krunidbenom ornatu. ${ }^{62} \mathrm{Na}$ spomeniku se nalazi natpis: "U spomen hiljadugodišnjice prvog hrvatskog kralja Tomislava 925-1925 podigoše Hrvati sela i grada Livna". ${ }^{63} \mathrm{U}$ programu proslave navodi se da je spomenik postavljen na Trgu Zrinski dok se u Kronici franjevačkoga samostana navodi da je spomenik postavljen "na lijepom mjestu u Splitskoj ulici i to mjesto odasle nosi ime trg Kralja Tomislava". ${ }^{64}$ Postojali su prijepori o lokaciji između odbora za podizanje spomenika na čelu s fra Jakom Pašalićem i gradskih vlasti na čelu s gradskim komesarom Mustafom Mulalićem. Nesuglasice su dovele do toga da je komesar bojkotirao svečanosti, a

60 Isto.

61 AFSG, Kronika FranjevaČKoga samostana na Gorici, Ljet. 1 (kut. 7), str. 269.

62 M. Jareb, Kralj Tomislav kroz tisuć godina, str. 214.

63 Spomenik je oštećen krhotinom avionske bombe prilikom savezničkoga bombardiranja u svibnju 1944. Trg je preuređen 1977. zadržavši svoj oblik do danas sa spomenikom kojemu se posvećuje više pozornosti u održavanju nakon Domovinskoga rata. Usp. http://www.matica.hr - Stipo ManĐeralo, Trg kralja Tomislava u Livnu, Livno, 2009. (24. 4. 2020.).

64 AFSG, Kronika franjevačKoga samostana na Gorici, Ljet. 1 (kut. 7), str. 269. Za vrijeme komunističke vlasti Trg kralja Tomislava preimenovan je u Trg maršala Tita, a 1992. ponovo je vraćen naziv Trg kralja Tomislava. Usp. http://www.matica.hr - Stipo ManĐeralo, Trg kralja Tomislava u Livnu, Livno, 2009. (24. 4. 2020.). 
proslavu su bojkotirali i srpsko pjevačko i tamburaško društvo Sundečić te muslimansko kulturno-umjetničko društvo Sloga ${ }^{65} \mathrm{U}$ okviru svečanosti organiziran je banket u prostorijama Hrvatskoga glazbenopjevačkog društva Dinara na kojemu je bio velik broj gostiju, a poslije 15 sati organizirana je velika pučka zabava. ${ }^{66}$

\section{Proslave obljetnice u Mostaru}

Po uzoru na Zagreb cijela Hercegovina je 5. srpnja 1925. proslavila tisućgodišnjicu Hrvatskoga Kraljevstva, s većim bojkotiranjem proslave u Mostaru. Kako po ostaloj Hercegovini, tako i u Mostaru proslava je uslijedila na poticaj crkvenih vlasti koje su više puta pozivale sva hrvatska društva i građane na dogovor kako bi ova rijetka proslava prošla što bolje i veličanstvenije, ali stvari nisu išle glatko. Naime, nisu došli lokalni hrvatski predstavnici u vlasti jer su se, prema pisanju Narodne slobode, uvrijedili zbog kritike iz crkvenih redova ${ }^{67}$ Radi se o članovima HSS-a i njihovim simpatizerima koji su bojkotirali crkvenu proslavu. U Hercegovini je većina svećenstva Katoličke Crkve, neki javno a neki tajno, stajala na strani Hrvatske pučke stranke ${ }^{68}$ a protiv Radićeva HSS-a. ${ }^{69}$ Seoski se svijet iz dva ra-

65 http://www.matica.hr - Stipo ManĐeralo, Trg kralja Tomislava u Livnu, Livno, 2009. (24. 4. 2020.).

66 ABiH, Središnja uprava HKD Napredak 1926., kutija 36, Arhiv. broj 401-1007. Plakat i program proslave u Livnu.

67 "Proslava 1000-godišnjice hrvatskog kraljevstva u Mostaru", u: Narodna sloboda, 27, Mostar, 10. srpnja 1925., str. 1.

68 "Hrvatska pučka stranka bila je relativno mala, ali ne i beznačajna politička organizacija koja je djelovala u Hrvatskoj, te Bosni i Hercegovini u parlamentarnom razdoblju nekadašnje Kraljevine Srba, Hrvata i Slovenaca. Od suvremenika, a i kasnije hrvatske (i bivše jugoslavenske) historiografije i publicistike, najčešće je označavana kao 'klerikalna' ili 'popovska' stranka. (Popularni je naziv za članstvo i pristaše HPS-a bio - 'pučkaši' ili kako su se sami voljeli nazivati 'pučani'.) Međutim, ne ulazeći podrobnije u to što je klerikalizam i je li ga uopće bilo u djelovanju hrvatskih političkih stranaka, recimo ovdje da se u slučaju HPS-a radilo o stranci koja je svoj program temeljila na kršćanskim načelima. Svoje je ishodište ova stranka imala u Hrvatskom katoličkom pokretu (HKP), nastalom početkom XX. st. pod neposrednim utjecajem krčkog biskupa Antuna Mahnića, te je zapravo predstavljala njegovu političku granu." Zlatko Matijević, "Politika Hrvatske pučke stranke u vrijeme atentata na hrvatske zastupnike u Narodnoj skupštini Kraljevine SHS (1927.-1928. godine)", u: Časopis za suvremenu povijest, Zagreb, 2/1995., str. 233.

69 Z. Matijević, U sjeni dvaju orlova, str. 212. 
Ivica Glibušić - Proslave tisućgodišnjice Hrvatskoga Kraljevstva...

zloga odazvao u malom broju. Prvi je što je seljaštvo u Hercegovini podržavalo HSS i njegovu politiku, što su pokazali rezultati izbora 1923. i 1925. kada je Radićev HSS osvojio većinu hrvatskih glasova a vjerojatno i njegov odnos prema crkvenoj proslavi. Drugi razlog nedolaska seljaštva može se tražiti u tome što su okolna sela oko Mostara i zapadna Hercegovina komunikacijski bila slabo povezana $s$ Mostarom. Na proslavu su, na poziv organizatora, došli predstavnici vojske i dio predstavnika civilne vlasti kao i izaslanstva srpskih društava Gusle i Pobratim i muslimanskoga društva Ittihada. Građanstvo koje je podržavalo HSS bojkotiralo je samu proslavu obljetnice. Narodna sloboda za bojkot je optužila dio političkih vođa koji se protive crkvenoj organizaciji proslave. ${ }^{70}$ Ovu proslavu bojkotirala su i hrvatska društva među kojima i Hrvoje. Iz nekih sela nitko nije došao na proslavu a posebno se ističe Jasenica koja je u potpunosti bojkotirala proslavu. Narodna sloboda navodi da su vođe "čistog hrvatstva" (odgovornim za bojkot proslave u Mostaru i Hercegovini smatralo se vodstvo lokalnog HSS-a u Hercegovini koje je slijedilo politiku Stjepana Radića op.a.) odvratile narod od proslave ističući kako se radi o crkvenoj proslavi a ne hrvatskoj. Posebno se problematiziralo zašto je Hrvatska glazba ${ }^{71}$ tražila da se plati njezin nastup na spomenutoj svečanosti. Narodna sloboda ističe da je prevladalo mišljenje kako na takvoj svečanosti trebaju govoriti biskup i svećenici a nikako predstavnici Hrvata u vlasti. "Sve što se radi i poduzima mora po njihovu nazoru nositi na sebi žig najradikalnijeg njihova 'hrvatstva'. Ne smeta njih da se njihovi 'meštri' grle danas u Beogradu sa najvišim protivnicima od jučer", navodi Narodna sloboda. ${ }^{72} \mathrm{HPS}$

70 "Proslava 1000-godišnjice hrvatskog kraljevstva u Mostaru", u: Narodna sloboda, 27, Mostar, 10. srpnja 1925., str. 1.

71 Hrvatsko glazbeno-pjevačko društvo Hrvoje osnovano 1888. pod imenom Narodno pjevačko društvo, a 1899. mijenja ime u Hrvatsko glazbeno-pjevačko društvo Hrvoje. U sklopu tog društva 1890. osnovana je Glazbena sekcija (Hrvatska glazba), zatim Ženski zbor, Mješoviti zbor, Dramska i Recitatorska sekciju, a 1899. postaje članom Saveza hrvatskih pjevačkih društava u Hrvatskoj. Hrvoje osniva Knjižnicu i Javnu čitaonicu, a organiziranjem dobrotvornih zabava pomaže novoosnovano Žensko sirotište. Surađuje i s Napretkom, potpomažući školovanje siromašnih đaka. Glazbena se sekcija 1918. izdvaja iz Hrvoja kao Hrvatska glazba. Hrvatsko glazbeno-pjevačko društvo Hrvoje Mostar, 120. obljetnica, Fram Ziral, Mostar, 2009., str. 54. Usp. http://www. matica.hr - Darko Juka, Hod kroz povijest (28. 4. 2020.).

72 "Proslava 1000-godišnjice hrvatskog kraljevstva u Mostaru", u: Narodna sloboda, 27, Mostar, 10. srpnja 1925., str. 2. 
preko svoga glasila Narodna sloboda nastojao je za sebe steći političku korist zbog Radićeva približavanja srpskim radikalima. Političke vođe (uglavnom članovi HSS-a) i njima odani građani nisu nazočili toj proslavi. Na proslavi nije bilo Hrvatskoga pjevačkog društva $\mathrm{Hr}$ voje ni njegove zastave, a nazočilo je malo građana. Hrvatske zastave nisu postavljene na hrvatskim kućama po Mostaru, a također nije bilo ni posebne rasvjete koja je trebala osvijetliti cijeli grad. Prema pisanju Narodne slobode "vođe čistog hrvatstva" odvratile su narod od proslave pod izgovorom da je to crkvena proslava a ne hrvatska, da je ćirilo-metodski dan "srpska godovina", da će Hrvati upriličiti jednu veličanstvenu proslavu čim se političke prilike do jeseni srede, da treba čekati odobrenje iz Zagreba. Upućena je kritika hrvatskim političarima u Mostaru kako ne prihvaćaju da od Crkve išta počinje, pogotovo da ne smije vodstvo pri ovakvim proslavama biti u rukama crkvenjaka. "Proslavu oni moraju upriličiti, na njoj glavnu riječ voditi i iz toga kapitala sebi što bolje izvući jer samo i jedino oni imaju pravo na hrvatstvo", navodi Narodna sloboda..$^{73}$ Organizatorima proslave posebno je zasmetalo što je zatraženo da Hrvatska glazba može nastupiti uz uvjet da joj Crkva plati i da nitko od građana ne smije držati govor a da to može učiniti samo biskup ili koji drugi crkvenjak. ${ }^{74} \mathrm{Na}$ dan proslave, 4 . srpnja uvečer, gradom je prošla Hrvatska glazba, osamljena, bez pratnje drugih svečara ili običnoga puka. Unatoč neslaganjima oko proslave u Mostaru, orlovska sekcija "Katarine Zrinjske"75 priredila je zabavu u subotu, 4. srpnja 1925., u dvorištu samostana časnih sestara franjevki. Ovdašnja podružnica Napretka priredila je koncert u hotelu Neretva, 5. srpnja 1925., na sv. Ćirila i Metoda, koji je i Napretkov dan. ${ }^{76}$

Drugi dan u deset sati služena je sveta misa zahvalnica koju je slavio provincijal fra Lujo Bubalo uza svečanu asistenciju više svećenika. Prigodnu propovijed održao je biskup Alojzije Mišić. Mnogima u cr-

73 Isto.

74 Isto.

75 Orlovska sekcija djelovala je u sklopu "Hrvatskog katoličkog djevojačkog društva Katarina Zrinjska". "Proslava 1000-godišnjice hrvatskog kraljevstva u Mostaru", u: Narodna sloboda, 27, Mostar, 10. srpnja 1925., str. 4; Katolički Episkopat u Jugoslaviji o katoličkom orlovstvu "Pastirski list svemu Svećenstvu Vrhbosanskom o katoličkom Orlovstvu", u: Vrhbosna, 5-6, Sarajevo, 20. ožujka 1924., str. 33-34.

76 "Proslava 1000-godišnjice hrvatskog kraljevstva u Mostaru", u: Narodna sloboda, 27, Mostar, 10. srpnja 1925., str. 4. 
Ivica Glibušić - Proslave tisućgodišnjice Hrvatskoga Kraljevstva...

kvenim krugovima zasmetalo je što je Hrvoje u zadnji čas javilo da ne može pjevati prigodom ove svečanosti. Iako je bila najavljena, procesija nakon mise nije održana zbog kiše što je proslavu učinilo još skromnijom. Narodu je pred crkvom govor održao Žarko Vlaho, ${ }^{77}$ istaknuti član HPS-a za Hercegovinu, a govorio je o značenju obilježavanja tisućgodišnjice Hrvatskoga Kraljevstva za hrvatski narod. Nakon toga Hrvatska glazba odsvirala je jednu skladbu i s tim činom proslava se završila. ${ }^{78}$

Druga masovnija proslava iza koje je stajao HSS, odnosno njihovi predstavnici u vlasti, uz organizaciju Hrvatskoga kulturnog društva Napredak, uslijedila je početkom listopada. Podružnica Napretka iz Mostara 27. rujna 1925. uputila je poziv "Bratskoj središnjoj upravi Napretka u Sarajevu" kako će podružnica iz Mostara uza sudjelovanje svih kulturnih društava 3. i 4. listopada 1925. proslaviti milenijsku obljetnicu Hrvatskoga Kraljevstva. Na proslavu u Mostar pozvana je Središnja uprava Napretka. ${ }^{79} \mathrm{Na}$ prijedlog akademskoga slikara Vilke Šeferova, a kako bi se tisućgodišnjica Hrvatskoga Kraljevstva što svečanije proslavila te u narodu probudila što jaču svijest o slavnoj povijesti hrvatskoga naroda, umjetnik Franjo Cota izradio je plaketu koja predstavlja kralja Tomislava koji sjedi na prijestolju okrunjen sa žezlom u ruci. ${ }^{80}$ Iz Mostara je poslan plakat za proslavu tisućgodišnjice Hrvatskoga Kraljevstva po odbornici podružnice Napretka u Mostaru, Jelki Ostojić. Također od ravnatelja je zatraženo da se u Mostar pošalju obećani lampioni za ukrašavanje grada ${ }^{81}$ Hrvatsko kulturno društvo Napredak, podružnica u Mostaru u zajednici sa svim ostalim hrvatskim društvima grada Mostara uputilo je poziv građanstvu za sudjelovanje 3. i 4. listopada 1925. na svečanoj

77 Žarko Vlaho, sreski kandidat HPS-a za Mostar a obnašao je i dužnosti tajnika HPS-a te urednika Narodne slobode, stranačkoga lista HPS-a u Hercegovini.

78 "Dan proslave 1000 godišnjice hrvatskog kraljevstva u Mostaru", u: Narodna sloboda, 27, Mostar, 10. srpnja 1925., str. 4.

79 ABiH, HKDN, 1925., Arhiv. broj 848-1186., broj spisa 901/1.

80 ABiH, HKD Napredak 1924., kutija 31, Arhiv. broj 1844-1972., 1925., kutija 31, Arhiv. broj 1-460., broj spisa 1938.

81 Od ravnatelja Napretka zatraženo je da ishodi dozvolu za prodaju duhana na stadionu Zrinjski za dan 4. listopada 1925., za Luizu Hlavaček koja ima već koncesiju ali za druge dijelove grada; ABiH, HKD Napredak, 1925., kutija 33, Arhiv. broj 848-1186., broj spisa 901/1. 
proslavi tisućgodišnjice Hrvatskoga Kraljevstva.$^{82} \mathrm{U}$ subotu večer (3. listopada) cijeli je grad bio osvijetljen a kuće su bile okićene vijencima i hrvatskim zastavama. Na Podveleži vidjelo se svjetlom označeno A. T. (Aleksandar i Tomislav) i dva tri svijetnjaka na okolnim brdima ${ }^{83}$ Ovim slovima željelo se pokazati kako Hrvati uza svoga prvoga kralja Tomislava, "priznaju kao svog i kralja Aleksandra", što je plod ulaska HSS-a u vlast sa srpskim radikalima a samim time i priznavanje kralja i Vidovdanskoga ustava. U večernjim satima (subota 3. listopada) održana je bakljada svih kulturnih društava u Mostaru, praćena Hrvatskom i Vojnom glazbom. ${ }^{84}$ Bakljada je pošla s Guvna, ${ }^{85}$ Šetalištem vojvode Mišića ${ }^{86}$ preko Balinovca, Zahum ulicom, ispred Hrvoja, Podhum ulicom zatim Lučkim mostom, Lučkom ulicom, Glavnom ulicom, Novom ulicom pred hotel Neretvu, gdje je svečanost otvorio prigodnim govorom predsjednik pripravnoga odbora za proslavu tisućgodišnjice Hrvatskoga Kraljevstva fra Leo Petrović. ${ }^{87}$ Nakon toga održan je koncert Hrvatske glazbe pred

82 U pozivu su stavljene cijene ulaznica za pučku svečanost na igralištu Hrvatskoga športskog kluba Zrinjski: sjedalo 10 dinara a za stajanje 5 dinara po osobi. Također su navedene cijene za svečanu zabavu koja će se održati u palači Hrvoje u nedjelju u večernjim satima s cijenama: krug 30 dinara, 1 mjesto 25 dinara, drugo mjesto 15 dinara i galerija deset dinara. Prodaja ulaznica za pučku svečanost i večernju zabavu u Hrvoju organizirana je u knjižari Merkur do uključivo 3. listopada, 4. listopada ulaznice su prodavane u Hrvoju a u večernjim satima samo na blagajni Hrvoja. Također prilikom ovih svečanosti organizirana je prodaja prigodne spomen značke po 5, 10 i 50 dinara. ArHIV HercegovaČKe franjeVaČKe Provincije u Mostaru (dalje: AHFPM), Spisi provincije (Dalje: SP), sv. 70, str. 178.

83 "Proslava 1000-godišnjice hrvatskog kraljevstva u Mostaru", u: Narodna sloboda, 40, Mostar, 7. listopada 1925., str. 1.

84 Isto.

85 Danas Trg hrvatskih velikana (Rondo).

86 Dio ulice Šetalište vojvode Mišića danas nosi naziv Ulica kneza Branimira od Trga hrvatskih velikana (Rondo) do križanja s Ulicom nadbiskupa Čule.

87 Fra Leo Petrović rodio se u zaseoku Poljane župe Klobuk 28. veljače 1883., a na krštenju je dobio ime Grgo. U franjevački je red stupio 4. listopada 1900. Za svećenika je zaređen 30. srpnja 1905. u Fribourgu. Profesor je teologije u Mostaru 1. svibnja 1907. - 8. svibnja 1917. Tajnikom je Hercegovačke franjevačke provincije 1910.-1915. Od 15. lipnja 1919. do 27. travnja 1925. gvardijan je u Mostaru. Dana 22. lipnja 1926. postaje bilježnikom na biskupskom ordinarijatu i ostaje na toj službi do 22. travnja 1935., da bi 23. travnja 1935. postao zamjenikom biskupa do 3. srpnja 1943. Na provincijskom kapitulu 3. srpnja 1943. izabran je za provincijala Hercegovačke franjevačke provincije Uznese- 
Ivica Glibušić - Proslave tisućgodišnjice Hrvatskoga Kraljevstva...

hotelom Neretva. ${ }^{88}$ Čitlučki tamburaški zbor, pod vodstvom upravitelja škole na Čitluku Marka Pavičića, koji je poput ostalih pjevača bio odjeven u narodnu seljačku nošnju, odsvirao je i otpjevao nekoliko narodnih pjesama. ${ }^{89}$ Drugi dan, 4 . listopada (nedjelja) 1925. u devet sati održana je svečana sveta misa na Guvnu i šetalištu Vojvode Mišića. ${ }^{90}$ Misno slavlje predvodio je biskup Alojzije Mišić dok su iznad grada kružili vojni zrakoplovi. ${ }^{91} \mathrm{U}$ deset sati formirana je svečana povorka svih kulturnih društava, škola, okolnih župa, vojske i građanstva. $\mathrm{Na}$ čelu povorke bila su dva seljaka, konjanika, s barjacima, iza njih sokolska konjica, seljačka konjica, vojna glazba i vojska, zatim izviđači, iza njih slijedile su škole: Prva djevojačka narodna osnovna škola; Druga djevojačka narodna osnovna škola; Prva dječačka osnovna škola; Druga dječačka narodna osnovna škola; iza njih Vježbaonica; Škole sestara Milosrdnica (viši razredi); Viša djevojačka škola; Ženska stručna škola; Velika gimnazija (muška), Trgovačka škola; Učiteljska škola; Sokolska župa Alekse Šantića (sa zastavom); Jugoslavensko sokolsko društvo (s članstvom svih kategorija). Nakon njih slijedila su športska društva: Hrvatski športski klub Zrinjski; Športski klub Vardar; Jugoslavenski športski klub i Radnički športski klub Velež..$^{2}$ Nakon njih u povorci su sudjelovali odbori raznih društava koja su djelovala na području Mostara. U povorci su sudjelovali predstavnici vjerskih, gradskih i vojnih vlasti, Centralni svečani odbor, Hrvatski sokol, Hrvoje (sa zastavama), seljaštvo po župama sa zastavama, Hrvatska glazba i na kraju povorke kretalo se građanstvo. ${ }^{93}$ Narodna sloboda se vrlo kritički osvrnula na navedenu proslavu ističući kako je u povorci bilo malo ljudi (samo 3500), te je na taj način nastojala umanjiti masovnost ove proslave zbog politič-

nja Blažene Djevice Marije i tu službu obnaša do svoje mučeničke smrti 14. veljače 1945. Sedmoricu franjevaca, na čelu s fra Leom, partizani su ubili i bacili u Neretvu. http://www.pobijeni.info - Fra Ante Marić, Dr. fra Leo Petrović, O svemu su poslije potajno svjedočili preživjeli fratri (27. 4. 2020.).

88 AHFPM, SP, sv. 70, str. 179.

89 "Proslava 1000-godišnjice hrvatskog kraljevstva u Mostaru", u: Narodna sloboda, 40, Mostar, 7. listopada 1925., str. 1.

90 Prostor na kojem je služena misa: danas Trg hrvatskih velikana (Rondo), ulica Nikole Šubića Zrinskog i park Zrinjevac (op. a.).

91 "Proslava 1000-godišnjice hrvatskog kraljevstva u Mostaru", u: Narodna sloboda, 40, Mostar, 7. listopada 1925., str. 1.

92 AHFPM, SP, sv. 70, str. 180.

93 AHFPM, SP, sv. 70, str. 181. 
kih interesa HPS-a. Nastojalo se prikazati proslavu manjkavom zbog toga što su se muslimani od nje gotovo potpuno distancirali. Posebno se ističe mala nazočnost seljaštva na proslavi (500-600 osoba). Veći broj seljaka došao je iz Bijelog Polja i Blagaja, dočim od Širokog Brijega, Ljubuškog i Brotnja došli su samo odbornici HSS-a. ${ }^{94}$ Jedan od razloga nedolaska seljaštva iz zapadne Hercegovine u Mostar kao i kod prve proslave jest izrazito slaba komunikacijska povezanost s Mostarom. Povorka je krenula šetalištem Vojvode Mišića, zatim Ulicom kralja Petra do Srednje ulice ${ }^{95}$ gdje je obavljeno proglašenje Srednje ulice Ulicom kralja Tomislava ${ }^{96}$ Proglašenje ulice obavio je povjerenik grada (komesar) Smail Ćemalović, održavši prigodan govor i otkrivši ploču na kojoj je zlatnim slovima bilo urezano Ulica Kralja Tomislava. ${ }^{97}$ Povorka se dalje kretala Ulicom kralja Tomislava, Lukom ulicom preko Lučkog mosta, te Podhumom do Hrvoja gdje je održan govor u spomen tisućgodišnjice Hrvatskoga Kraljevstva. Govor je održao Bariša Smoljan, predstavnik HSS-a u Mostarskoj oblasti. Nakon toga otkrivena je spomen ploča a tom prigodom fra Leo Petrović je pozdravio predstavnike vlasti te otkrio spomen ploču na zgradi Hrvoja s natpisom "Na spomen 1000-godišnjice krunisanja I. hrvatskoga kralja Tomislava. Hercegovački Hrvati 4. oktobra 1925."98 Ploča je predstavljala znak zahvalnosti Hrvata iz Hercegovine prvom hrvatskom kralju. ${ }^{99}$

Poslijepodne organizirana je velika pučka svečanost na igralištu Hrvatskoga športskog kluba Zrinjski kod Zapadnoga logora. ${ }^{100} \mathrm{Na}$ pučkoj zabavi nastupili su tamburaški zborovi iz Bijelog Polja, Trebižata i Ćitluka. ${ }^{101}$ Oko tri sata poslijepodne započele su kup utakmice na igralištu Zrinjskoga, svih mjesnih športskih klubova za milenijski srebreni vrč (pehar). U finalu su igrali Hrvatski športski klub Zrinj-

94 "Proslava 1000-godišnjice hrvatskog kraljevstva u Mostaru", u: Narodna sloboda, 40, Mostar, 7. listopada 1925., str. 1.

95 Danas Ulica braće Fejića. Vidi: Karlo Drago Miletić, "Prvi brojevi na mostarskim kućama", u: Motrišta, 22, Mostar, 2001., str. 138-139.

96 AHFPM, SP, sv. 70, str. 179.

97 "Proslava 1000-godišnjice hrvatskog kraljevstva u Mostaru", u: Narodna sloboda, 40, Mostar, 7. listopada 1925., str. 1.

98 Isto.

99 Hrvatsko glazbeno-pjevačko društvo Hrvoje Mostar, 120. obljetnica, str. 31.

100 Staro igralište, danas Ulica kralja Tomislava (op.a.).

101 AHFPM, SP, sv. 70, str. 179. 
Ivica Glibušić - Proslave tisućgodišnjice Hrvatskoga Kraljevstva...

ski i Jugoslavenski športski klub. Nakon neodlučenog rezultata primijenilo se pravilo izvlačenja imena pobjednika. Utakmicu je dobio Zrinjski. ${ }^{102}$ Milenijski pehar pobjedniku uručio je Jakiša Milković, ${ }^{103}$ mostarski odvjetnik i istaknuti član HSS-a u Hercegovini. Jugoslavensko sokolsko društvo u Mostaru izvodilo je na spravama sokolske vježbe. Također održano je štafetno trčanje, trčanje u vrećama i penjanje na stup. ${ }^{104} \mathrm{U}$ večernjim satima održana je velika svečana zabava s plesom u Hrvoju sa sljedećim programom: V. Novak: Hrvatskoj, pjeva muški mješoviti zbor Hrvoje; P. Kriškovsky: Utopljena, pjeva muški zbor Hrvoje; ${ }^{105}$ Mokranjac, VII rukovet, nije izveden jer Srpsko pjevačko društvo Gusle, iako je bilo najavljeno, nije nastupilo pod izgovorom tehničkih razloga. ${ }^{106}$ Mokranjac: Kozar, pjeva mješoviti zbor Hrvoje; Krunisanje kralja Tomislava izvodi Sokolsko društvo u Mostaru; Bog i Hrvati, izvodi Hrvatski katolički Orao; Dalmatinski šajkaš, izvode članice orlovske sekcije Katarine Zrinjske; Duvanjsko polje, od dr. Zdeneke Smrekar, izvode pitomice čč. ss. sv. Franje. ${ }^{107}$

U organiziranju druge proslave tisućgodišnjice Hrvatskoga Kraljevstva u Mostaru Napredak je bio nositelj svih aktivnosti. Kako bi proslava prošla što veličanstvenije, pripomogle su lokalne političke vlasti predvođene dužnosnicima HSS-a. Također proslavu je potpomogla i vojska, odnosno državne vlasti, na temelju ulaska HSS-a u vlast sa srpskim radikalima na državnoj razini. Poseban doprinos samoj proslavi dalo je Hrvatsko glazbeno pjevačko društvo Hrvoje s nastupima više sekcija, koje su uzveličale proslavu tisućgodišnjice Hrvat-

102 "Proslava 1000-godišnjice hrvatskog kraljevstva u Mostaru", u: Narodna sloboda, 40, Mostar, 7. listopada 1925., str. 1.

103 Jakov Milković zvani Jakiša rođen je 1888. godine u Širokom Brijegu. Po završetku gimnazije nastavio je školovanje i stekao zvanje doktora pravnih znanosti a vremenom postaje poznati hercegovački odvjetnik. Kao odvjetnik djeluje na području Mostara i Stoca. Bio je jedan od uglednijih članova HSSa koja je u to doba bila izrazito utjecajna stanka među Hrvatima i koja je imala vlast u mostarskom i stolačkom kotaru. Obnašao je i funkciju posljednjega predsjednika HŠK Zrinjski. Strijeljali su ga partizani u Mostaru 17. travnja 1945. i praktički njegovim ubojstvom klub prestaje s radom. http://m.pogled. ba - Pogled u prošlost: U spomen na Miroslava Micana Kordića (27. 4. 2020.).

104 AHFPM, SP, sv. 70, str. 179.

105 Isto.

106 "Proslava 1000-godišnjice hrvatskog kraljevstva u Mostaru", u: Narodna sloboda, 40, Mostar, 7. listopada 1925., str. 1.

107 AHFPM, SP, sv. 70, str. 179. 
skoga Kraljevstva u Mostaru. ${ }^{108}$ Po završetku Drugoga svjetskog rata Ulica kralja Tomislava preimenovana je u Ulicu braće Fejića, tako da je jedini spomen na veliku obljetnicu privremeno nestao iz Mostara. Hrvati grada Mostara, nakon stjecanja slobode u Domovinskom ratu, u spomen na prvoga hrvatskoga kralja, najveću gradsku ulicu nazvali su Ulica kralja Tomislava. Na taj način simbolično je vraćeno sjećanje na veliku obljetnicu Hrvatskoga kraljevstva koja je proslavljena u Mostaru 1925. godine.

\section{Financijska bilanca proslava obljetnice}

U zapisniku XXII. redovite glavne godišnje skupštine Napretka održane od 4. do 7. srpnja 1926. u Sarajevu analizirana je proslava tisućgodišnjice Hrvatskoga Kraljevstva. Naglašeno je kako je vrijeme za organizaciju proslave bilo prekratko ali se uspješno organizirala a intencija Napretka bila je da se organizira u cijeloj BiH. Proslave su obavljene od rujna do prosinca. Centralna proslava održana je u Sarajevu. Za proslavu u Sarajevu, Ministarski savjet odobrio je pomoć od 50.000 dinara, a gradska općina 100.000 dinara. Glavna proslava za Hercegovinu održana je u Mostaru gdje je gradska općina dala 20.000 dinara, a mali dio hercegovačkih općina dao je svoje skromne priloge. Uz ove uslijedile su proslave i u drugim mjestima: u Visokom, Kaknju, Zgošći, Tesliću, Doboju, Travniku, Brčkom, Varešu, Čapliini i drugim mjestima. Za sve proslave prodavale su se "Tomislavove" značke u korist Napretka. Tom prilikom otkrivene su spomen ploče u Sarajevu, Mostaru, Zgošći, Kraljevoj Sutjesci, Čapljini a u nekim mjestima glavna ulica dobila je naziv "Tomislavova". Kako je proslava imala nacionalni karakter, nije se išlo za nekom materijalnom zaradom, ali je cjelokupna proslava imala prihod. Od ukupno uplaćenih 494.393.09 dinara, uz rashod od 384.118.70 dinara ostvarena je čista dobit od 110.275.20 dinara. ${ }^{109}$

108 Hrvatsko glazbeno-pjevačko društvo Hrvoje Mostar, 120. obljetnica, str. 31.

109 "Zapisnik XXII. redovite glavne godišnje skupštine 'Napretka' održane od 4. do 7. srpnja 1926.", u: "Napredak" hrvatski narodni kalendar za prostu godinu 1927., "Napredak" hrvatsko kulturno društvo u Sarajevu, Sarajevo, 1926., str. 34 . 
Ivica Glibušić - Proslave tisućgodišnjice Hrvatskoga Kraljevstva...

\section{Zaključak}

Proslave tisućgodišnjice Hrvatskoga Kraljevstva u Bosni i Hercegovini održane su po uzoru na proslave u Hrvatskoj. Slijedile su se upute s Biskupske konferencije iz Đakova a također i preporuke iz okružnice Družbe "Braća Hrvatskoga Zmaja" na koji način i što veličanstvenije obilježiti obljetnicu Hrvatskoga Kraljevstva. Proslave su organizirane u mjestima gdje su Hrvati činili značajan ili većinski udio u lokalnom stanovništvu od Bosanske Posavine preko središnje i zapadne Bosne do juga Hercegovine. Najveličanstvenije proslave organizirane su u Duvnu, Sarajevu i Mostaru.

Prilikom obilježavanja proslava tisućgodišnjice Hrvatskoga Kraljevstva u Bosni i Hercegovini došle su do izražaja političke podjele koje su otprije postojale među bosanskohercegovačkim Hrvatima. Posebno je bila izražena podjela u Mostaru koja je posljedica utjecaja političkih stranaka, posebno Hrvatske seljačke stranke koja je imala apsolutnu podršku Hrvata u BiH. Hrvatska pučka stranka, koja je imala podršku većega dijela franjevačkog svećenstva, podržavala je crkvenu proslavu tisućgodišnjice Hrvatskoga Kraljevstva. Utjecajnija stranka u hrvatskom narodu, Hrvatska seljačka stranka bojkotirala je crkvene proslave dajući podršku proslavama u organizaciji Napret$k a$ koju su podržavale i državne vlasti. U svim proslavama u kojima je tada sudjelovala Hrvatska seljačka stranka isticana je važnost nacionalnoga okupljanja oko obilježavanja tisućgodišnjice Hrvatskoga Kraljevstva.

U organizaciji obilježavanja obljetnice Hrvatskoga Kraljevstva u Bosni i Hercegovini glavnu riječ imalo je Hrvatsko kulturno društvo Napredak, a doprinos obilježavanju obljetnice dala su i druga hrvatska pjevačko-glazbena društva diljem Bosne i Hercegovine sudjelujući u manifestacijama kroz razne sekcije. Posebno velik doprinos dalo je Hrvatsko glazbeno-pjevačko društvo Hrvoje svojima nastupima u Mostaru i drugim mjestima u Bosni i Hercegovini. Obilježavanja tisućgodišnjice Hrvatskoga Kraljevstva kroz razne proslave koje su organizirane diljem Bosne i Hercegovine a u kojima je sudjelovao velik broj Hrvata pridonijela su učvršćivanju nacionalne svijesti i izgradnji hrvatskoga nacionalnog identiteta.

Kao trajan znak na tu proslavu i danas nas podsjećaju brojne spomen ploče, nazivi ulica i trgova, te spomenici s imenom kralja Tomislava. 


\section{Millenary celebrations of the Croatian King- dom in Bosnia and Herzegovina with particu- lar reference to Mostar}

\section{Summary}

On the basis of archive materials, press from that period and scientific literature the article shows a part of the millenary celebrations of the Croatian Kingdom in Bosnia and Herzegovina with particular reference to celebration in Mostar. It presents the circumstances in which the millenary was celebrated, what caused new divisions and politicization around the celebration and holding two celebrations in Sarajevo and Mostar, one in July and the other in September. Especially expressed was a division in Mostar as a consequence of political parties' influence, particularly Croatian Peasant Party, which had absolute support of the Croats in B\&H. Croatian People's Party, which had support of the majority of Franciscans, encouraged the Church celebration of the Croatian Kingdom millenary. More influential party for Croatian people, Croatian Peasant Party, boycotted the Church celebrations giving support to the other celebration organized by Napredak and supported by state authorities.

Croatian cultural society Napredak as the nonpartisan organization but with the members who were politicians, public officials and prominent ecclesiastical figures, had the upper hand in the organization of the Croatian Kingdom in Bosnia and Herzegovina millenary celebration. Participating in the manifestations through different sections other Croatian music-choral societies from all over Bosnia and Herzegovina also gave their contribution to the millenary celebration. Music-choral society Hrvoje gave the special contribution with their performances in Mostar and other places in Bosnia and Herzegovina. Significance of national gathering around the millenary celebration of the Croatian 
Ivica Glibušić - Proslave tisućgodišnjice Hrvatskoga Kraljevstva...

Kingdom was pointed out in all celebrations the Croatian Peasant Party participated in. Large number of Croats were involved in the celebrations organized all over Bosnia and Herzegovina, what contributed to strengthening national consciousness and developing Croatian national identity. Numerous memorial plates, names of streets and squares as well as monuments with the name of King Tomislav remind us of the celebration.

Keywords: millenary of the Croatian Kingdom; Napredak; Croatian Peasant Party; Catholic Church; Franciscans; Croatian People's Party. 